\title{
REVIEW \\ Greenhouse Gas Sink-Source Functions of Grassland Ecosystems
}

\author{
Akinori MORI \\ Institute of Livestock and Grassland Science, NARO (Nasushiobara, Tochigi 329-2793, Japan)
}

\begin{abstract}
This review summarizes research on greenhouse gas (GHG) exchange between the atmosphere and grasslands in Japan, identifies research need, and contributes to advances in the research field of GHG mitigation in grassland ecosystems. Applications of farmyard manure (FYM) and synthetic fertilizers do not reduce the ability of intensively managed grassland soils to oxidize methane $\left(\mathrm{CH}_{4}\right)$. On the one hand, the use of synthetic fertilizers alone reduces the net ecosystem carbon balance (NECB) of mowed grassland ecosystems. On the other hand, the application of FYM with supplemental synthetic fertilizers at rates determined from the mineralization of FYM increases the NECB at the same yields, due mainly to $\mathrm{C}$ brought into the ecosystem as FYM. It also limits further emissions of nitrous oxide $\left(\mathrm{N}_{2} \mathrm{O}\right)$. Precipitation before and after fertilization in the summer months is the key driver of interannual variation in $\mathrm{N}_{2} \mathrm{O}$ emissions. These findings collectively suggest that the application of FYM with the appropriate reduction in supplemental synthetic fertilizers can maintain soil organic $\mathrm{C}$ and maximize the net GHG balance of mowed grassland ecosystems in Japan. Studies on organic matter inputs through root growth and turnover, and models to predict large $\mathrm{N}_{2} \mathrm{O}$ fluxes are needed to enhance our understanding of the NECB and net GHG balance of grassland ecosystems.
\end{abstract}

Discipline: Agricultural environment, Grassland

Additional key words: carbon balance, farmyard manure, methane, nitrous oxide, soil

\section{Introduction}

In Japan, meadows and pastures (covering ca. 0.62 million ha) account for $13.4 \%$ of the total agricultural land area (ca. 4.63 million ha; MAFF 2014). These areas plus natural, semi-natural, and non-agricultural grasslands (ca. 1.87 million ha) cover $5.0 \%$ of Japan's total land area (Matsuura et al. 2012). Well-drained Andosols (31\%) or brown forest soils (33\%) account for about two-thirds of the soil under grasslands in Japan.

Most manure derived from dairy and beef cattle in Japan is composted before being applied to agricultural land (GIO 2014). Bark, sawdust, and rice straw are often added to such mature to promote composting. A substantial proportion of this manure is derived from imported feedstuffs (Hojito et al. 2003). And because the manure thus represents a net import of organic matter (OM) into Japan, it must be properly applied for fertility management and to avoid the increased emission of greenhouse gases (GHGs) from soil. The application of farmyard manure (FYM) to grassland increases the input of OM into soil both directly through the manure itself, and indirectly through the promo- tion of plant growth. To evaluate the net GHG balance of grassland, the emissions of methane $\left(\mathrm{CH}_{4}\right)$ and nitrous oxide $\left(\mathrm{N}_{2} \mathrm{O}\right)$ from grasslands should be taken into account (Fig. 1). This review summarizes the research on GHG exchange in Japan, identifies research needs, and contributes to advances in the research field of GHG mitigations in grassland ecosystems.

\section{$\mathrm{CH}_{4}$ oxidation and emissions from grasslands in Japan}

$\mathrm{CH}_{4}$ is a GHG with a lifespan of 12.4 years; its global warming potential is 34 times that of carbon dioxide $\left(\mathrm{CO}_{2}\right)$ over a time frame of 100 years (Myhre et al. 2013).

The annual emissions of $\mathrm{CH}_{4}$ from mowed grassland plots at four sites across the range of climate zones in Japan (from Hokkaido to Kyushu) ranged from -1.9 to $5.5 \mathrm{~kg} \mathrm{C}$ $\mathrm{ha}^{-1}$ year $^{-1}$ (Shimizu et al. 2013). In most cases, however, the soil under grassland functions as a sink for atmospheric $\mathrm{CH}_{4}$ (i.e., with negative net $\mathrm{CH}_{4}$ emission values).

The application of ammonium fertilizer reduces the ability of soil under natural grasslands to oxidize $\mathrm{CH}_{4}$ 


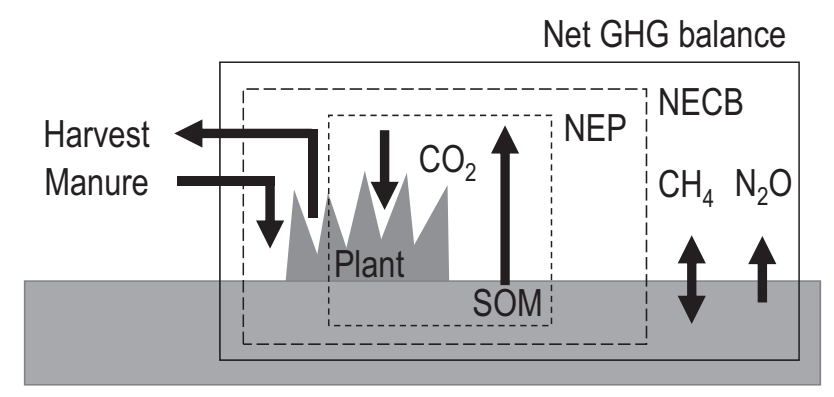

Fig. 1. Component fluxes of the net GHG balance of mowed grassland. GHG, greenhouse gas; NECB, net ecosystem carbon balance; $\mathrm{NEP}$, net ecosystem production; $\mathrm{CH}_{4}$, methane; $\mathrm{N}_{2} \mathrm{O}$, nitrous oxide; SOM, soil organic matter

(Mosier et al. 1991). However, ammonium fertilizer applied periodically does not decrease the $\mathrm{CH}_{4}$ oxidizing ability of soil under intensively managed grasslands (Shimizu et al. 2013), partly due to an increase in ammonium-oxidizing microbial species capable of oxidizing $\mathrm{CH}_{4}$ in the soil (Bodelier \& Laanbroek 2004). By regulating the diffusion of oxygen and $\mathrm{CH}_{4}$, soil moisture content also controls the rate of $\mathrm{CH}_{4}$ oxidation on the surface (Mori et al. 2005, Sawamoto et al. 2010). $\mathrm{CH}_{4}$ was emitted from poorly drained grassland because soil moisture promotes microbial methanogenesis (Shimizu et al. 2013).

The surface application of manure slurry moderately increases the annual emissions of $\mathrm{CH}_{4}$ from grassland (1.4$3.0 \mathrm{~kg} \mathrm{C} \mathrm{ha}^{-1}$ year $^{-1}$ ), while the surface application of composted FYM results in a smaller increase (less than 1.0 $\mathrm{kg} \mathrm{C} \mathrm{ha}^{-1}$ year $^{-1}$, Mori and Hojito 2011, 2015a). Anaerobic decomposition of the dung of grazing cattle just after deposition on grazing land is another source of $\mathrm{CH}_{4}$, but urine deposition does not increase $\mathrm{CH}_{4}$ emissions, owing to an increase in ammonium-oxidizing microbial species as mentioned above, because the grassland has received urine- $\mathrm{N}$ of grazing cattle for decades (Mori and Hojito 2015b).

\section{Carbon balance of grasslands in Japan}

$\mathrm{CO}_{2}$ in grassland ecosystems is exchanged between the soil, plants, and atmosphere. Therefore, plant growth and the decomposition of soil organic matter (SOM) are components of net ecosystem production (NEP, Fig. 1). In managed grasslands, the application of manure (i.e., input of $\mathrm{C}$ into the ecosystem) and the harvesting of plants (i.e., output of $\mathrm{C}$ from the ecosystem) contribute significantly to the net ecosystem C balance (NECB, Fig. 1).

In mowed grassland plots at four sites across the range of climate zones in Japan (from Hokkaido to Kyushu), the NEP of C (NEP-C: $0.5-3.5 \mathrm{Mg} \mathrm{C} \mathrm{ha}^{-1}$ year $^{-1}$ ) of plots that received only synthetic fertilizers was smaller than the amount harvested (2.9-5.5 $\mathrm{Mg} \mathrm{C} \mathrm{ha}^{-1}$ year $^{-1}$ ), indicating that these plots lost C (Hirata et al. 2013). However, in the adjacent mowed grassland plots that received FYM plus supplemental synthetic fertilizers, the sum of NEP-C (0.12-2.63 Mg C ha ${ }^{-1}$ year $\left.^{-1}\right)$ and FYM-C (1.9-7.7 Mg C ha ${ }^{-1}$ year $\left.^{-1}\right)$ was greater than the amount harvested (3.2-5.2 $\mathrm{Mg} \mathrm{C}^{-1}$ year $\left.^{-1}\right)$, thus indicating that these plots gained $\mathrm{C}$. There was no significant difference between treatments in the amount harvested. Therefore, the difference in the NECB between the treatments was due mainly to FYM-C that remained undecomposed on the surface (Hirata et al. 2013). During the three-year observation period, the cumulative rate of decomposition was estimated to be $25 \% \pm 37 \%$ of the amount of FYM-C applied during the same period (Shimizu et al. 2014a, b). These results suggest that the application of FYM is necessary to maintain the soil organic C of mowed grasslands in Japan (Shimizu et al. 2009), and the effect of FYM application on the NECB is substantial due to the slower rate of decomposition than that of manure slurry (Mori and Hojito 2015c).

NEP during the first crop (i.e., grass growth during the spring period) in mowed grassland makes a significant contribution to annual NEP (Matsuura et al. 2014). It also occupies an important position in the annual NECB in C stocks belowground. Belowground $\mathrm{C}$ generally has a slower turnover rate than aboveground $\mathrm{C}$, as most organic $\mathrm{C}$ in soils (humic substances) is produced by the transformation of plant litter into more persistent organic compounds (Soussana et al. 2010). Future research should focus on the input of OM into grassland ecosystems through root growth and turnover, in order to enhance our understanding of the NECB of grassland ecosystems (Mori and Hojito 2015c).

Extensive management (including burning, grazing, and harvesting) is practiced to maintain semi-natural grassland, unlike intensive grassland. Semi-natural grassland, with traditional pasture species, usually receives no fertilizer. In the mountains of Aso, Japan, burning has been used for several thousand years to maintain Miscanthus sinensis 
grasslands (Toma et al. 2010). The rate of $\mathrm{C}$ accumulation in the soil of $M$. sinensis grasslands $\left(0.503 \mathrm{Mg} \mathrm{C} \mathrm{ha}^{-1}\right.$ year $^{-1}$ ) was greater than that in Cryptomeria japonica forest plantations (0.284 Mg C ha ${ }^{-1}$ year $^{-1}$; Toma et al. 2012). The mean soil organic $\mathrm{C}$ sequestration rates of semi-natural grassland in Aso over 34, 50, and 100 years were estimated to be $0.618,0.483$, and $0.332 \mathrm{Mg} \mathrm{C} \mathrm{ha}^{-1}$ year $^{-1}$, respectively (Toma et al. 2013).

\section{$\mathrm{N}_{2} \mathrm{O}$ emissions from grasslands in Japan}

$\mathrm{N}_{2} \mathrm{O}$ is a GHG with a lifespan of 121 years; its global warming potential is 298 times that of $\mathrm{CO}_{2}$ (Myhre et al. 2013). $\mathrm{N}_{2} \mathrm{O}$ also contributes to stratospheric ozone depletion (Ravishankara et al. 2009). Nitrogen (N) fertilizer is essential to maintaining production. Although it can increase the input of $\mathrm{OM}$ into the soil through enhanced plant growth, it can also increase the emissions of $\mathrm{N}_{2} \mathrm{O}$ into the atmosphere.

Microbial nitrification and denitrification of mineralizable $\mathrm{N}$ in the soil are the main causes of $\mathrm{N}_{2} \mathrm{O}$ emissions from unfertilized grassland ( $\mathrm{Mu}$ et al. 2009). $\mathrm{N}_{2} \mathrm{O}$ emissions increase with increasing $\mathrm{N}$ surplus, calculated as $\mathrm{N}$ inputs minus $\mathrm{N}$ uptake by forage (Shimizu et al. 2010). Therefore, the judicial application of organic plus inorganic $\mathrm{N}$ at rates determined from the mineralization of manure is crucial to mitigate $\mathrm{N}_{2} \mathrm{O}$ emissions. Manure storage conditions (i.e., composting vs. storage of manure slurry) have little impact on annual $\mathrm{N}_{2} \mathrm{O}$ emissions from soils under optimized fertility management (Mori and Hojito 2015a). In addition, the annual emissions of $\mathrm{N}_{2} \mathrm{O}$ from soils do not differ significantly between grassland plots that receive ammonium-N as anaerobically digested cattle slurry and plots that receive the same rate of ammonium-N as ammonium sulfate (Sawamoto et al. 2010).

The measurement of $\mathrm{N}_{2} \mathrm{O}$ emissions from mowed grassland plots at four sites across the range of climate zones in Japan has revealed that the mean $\mathrm{N}_{2} \mathrm{O}$ emission factor $(E F)$ of synthetic $\mathrm{N}$ fertilizer $(1.8 \% \pm 1.5 \%)$ is greater than that of FYM $(0.36 \% \pm 0.61 \%$; Shimizu et al. 2013 , Jin et al. 2010). The $\mathrm{N}_{2} \mathrm{O} E F$ of synthetic fertilizer $(0.1 \%$ $5.7 \%)$ increases with increasing annual mean air temperature $\left(5.2-15.8^{\circ} \mathrm{C}\right)$ and precipitation $\left(1160-2595 \mathrm{~mm} \mathrm{year}^{-1}\right)$, but the $\mathrm{N}_{2} \mathrm{O} E F$ of FYM $(-3.2 \%$ to $+1.3 \%)$ has shown no clear relationships (Shimizu et al. 2013). The smaller $\mathrm{N}_{2} \mathrm{O}$ $E F$ for FYM is due mainly to less inorganic $\mathrm{N}$ in FYM as compared with synthetic fertilizer (Mori and Hojito 2011). The background $\mathrm{N}_{2} \mathrm{O}$ emissions (0.2-4.2 $\mathrm{kg} \mathrm{N} \mathrm{ha}^{-1}$ year ${ }^{-1}$ ) also increase with increasing temperature and precipitation.

Annual $\mathrm{N}_{2} \mathrm{O}$ emissions show substantial variation between years. Variations in precipitation before and after the application of fertilizer, especially at ambient temperature higher than $15^{\circ} \mathrm{C}$, account for differences in $\mathrm{N}_{2} \mathrm{O}$ emis- sions between years, thereby suggesting that denitrification contributes significantly to $\mathrm{N}_{2} \mathrm{O}$ emissions because greater precipitation creates anoxic conditions that favor denitrifiers (Mori et al. 2008, Mori and Hojito 2012). A previous study in Hokkaido also suggests that high $\mathrm{N}_{2} \mathrm{O}$ fluxes in grassland plots result from increased denitrification activity (Katayanagi et al. 2008). Future research should focus on predicting high $\mathrm{N}_{2} \mathrm{O}$ fluxes, which contribute significantly to interannual differences in $\mathrm{N}_{2} \mathrm{O}$ emissions.

Excreta from grazing cattle are another source of $\mathrm{N}_{2} \mathrm{O}$. The $\mathrm{N}_{2} \mathrm{O} E F$ of dung $(0.024 \%)$ is much smaller than that of urine $(0.684 \%)$, possibly because dung- $\mathrm{N}$ is more refractory than urine-N (Mori and Hojito 2015b). The renovation of grassland (i.e., plowing, resowing) also increases $\mathrm{N}_{2} \mathrm{O}$ emissions (2.1-5.3 $\mathrm{kg} \mathrm{N} \mathrm{ha}^{-1}$ over 65-67 days), as does precipitation during and after renovation (Mori and Hojito 2007). In Hokkaido, less $\mathrm{N}_{2} \mathrm{O}$ trapped in frozen soil was released during a thaw from grassland plots than from cornfield plots, because more $\mathrm{N}_{2} \mathrm{O}$ that accumulated during the freezing and transition periods was reduced to $\mathrm{N}_{2}$ during the thaw in the grassland plots (Katayanagi and Hatano 2012).

\section{Conclusions}

The application of FYM with the appropriate reduction in supplemental synthetic fertilizers can maintain soil organic $\mathrm{C}$ and maximize the net GHG balance of mowed grassland ecosystems in Japan. Future research focusing on root growth and turnover, and models to predict large $\mathrm{N}_{2} \mathrm{O}$ fluxes are necessary to enhance our understanding of the NECB and net GHG balance of grassland ecosystems.

\section{References}

Bodelier, P. L. E. \& Laanbroek, H. J. (2004) Nitrogen as a regulatory factor of methane oxidation in soils and sediments. FEMS Microbiol. Ecol., 47, 265-277.

GIO (Greenhouse Gas Inventory Office of Japan) (2014) National greenhouse gas inventory report of Japan. National Institute for Environmental Studies, Tsukuba, Japan.

Hirata, R. et al. (2013) Carbon dioxide exchange at four intensively managed grassland sites across different climate zones of Japan and the influence of manure application on ecosystem carbon and greenhouse gas budgets. Agric. Forest. Meteorol., 177, 57-68.

Hojito, M. et al. (2003) Estimation of nitrogen loading in Japanese prefectures and scenario testing of abatement strategies. Nippon dojohiryo gakkaishi (Jpn. J. Soil Sci. Plant Nutr.), 74, 467-474 [In Japanese with English summary].

Jin, T. et al. (2010) Effect of chemical fertilizer and manure application on $\mathrm{N}_{2} \mathrm{O}$ emission from reed canary grassland in Hokkaido, Japan. Soil Sci. Plant Nutr., 56, 53-65.

Katayanagi, N. et al. (2008) Nitrous oxide and nitric oxide fluxes from cornfield, grassland, pasture and forest in a watershed in Southern Hokkaido, Japan. Soil Sci. Plant Nutr., 54, 662680 . 
Katayanagi, N. \& Hatano, R. (2012) $\mathrm{N}_{2} \mathrm{O}$ emissions during the freezing and thawing periods from six fields in a livestock farm, southern Hokkaido, Japan. Soil Sci. Plant Nutr., 58, 261-271.

MAFF (Ministry of Agriculture, Forestry and Fisheries) (2014) The 88th Statistical Yearbook of Ministry of Agriculture, Forestry and Fisheries (2012-2013), MAFF, Tokyo.

Matsuura, S. et al. (2012) Organic carbon stocks in grassland soils and their spatial distribution in Japan. Grassl. Sci., 58, 79-93.

Matsuura, S. et al. (2014) Seasonal carbon dynamics and the effects of manure application on carbon budget of a managed grassland in a temperate, humid region in Japan. Grassl. Sci., 60, 76-91.

Mori, A. et al. (2005) Effects of plant species on $\mathrm{CH}_{4}$ and $\mathrm{N}_{2} \mathrm{O}$ fluxes from a volcanic soil in Nasu, Japan. Soil Sci. Plant Nutr., 51, 19-27.

Mori, A. \& Hojito, M. (2007) Grassland renovation increases $\mathrm{N}_{2} \mathrm{O}$ emission from a volcanic grassland soil in Nasu, Japan. Soil Sci. Plant Nutr., 53, 812-818.

Mori, A. et al. (2008) $\mathrm{N}_{2} \mathrm{O}$ and $\mathrm{CH}_{4}$ fluxes from a volcanic grassland soil in Nasu, Japan: comparison between manure plus fertilizer plot and fertilizer-only plot. Soil Sci. Plant Nutr., 54, 606-617.

Mori, A. \& Hojito, M. (2011) Nitrous oxide and methane emissions from grassland treated with bark- or sawdust-containing manure at different rates. Soil Sci. Plant Nutr., 57, 138-149.

Mori, A. \& Hojito, M. (2012) Effect of combined application of manure and fertilizer on $\mathrm{N}_{2} \mathrm{O}$ fluxes from a grassland soil in Nasu, Japan. Agric. Ecosyst. Environ., 160, 40-50.

Mori, A. \& Hojito, M. (2015a) Effect of dairy manure type and supplemental synthetic fertilizer on methane and nitrous oxide emissions from a grassland in Nasu, Japan. Soil Sci. Plant Nutr., 61, 347-358.

Mori, A. \& Hojito, M. (2015b) Methane and nitrous oxide emissions due to excreta returns from grazing cattle in Nasu, Japan. Grassl. Sci., 61, 109-120.

Mori, A. \& Hojito, M. (2015c) Effect of dairy manure type on the carbon balance of mowed grassland in Nasu, Japan: comparison between manure slurry plus synthetic fertilizer plots and farmyard manure plus synthetic fertilizer plots. Soil Sci. Plant Nutr., 61, 736-746.

Mosier, A. R. et al. (1991) Methane and nitrous oxide fluxes in native, fertilized and cultivated grasslands. Nature, 350, 330332.

$\mathrm{Mu}$, Z. et al. (2009) Linking $\mathrm{N}_{2} \mathrm{O}$ emission to soil mineral $\mathrm{N}$ as estimated by $\mathrm{CO}_{2}$ emission and soil $\mathrm{C} / \mathrm{N}$ ratio. Soil Biol. Biochem., 41, 2593-2597.

Myhre, G. et al. (2013) Anthropogenic and Natural Radiative Forcing. In Climate Change 2013: In Physical Science Basis.
Contribution of Working Group I to the 5th Assessment Report of the Intergovernmental Panel on Climate Change, eds. Stocker, T. F., Qin, D., Plattner, G. -K., Tignor, M., Allen, S. K., Boschung, J., Nauels, A., Xia, Y., Bex, V., and Midgley, P. M., Cambridge University Press, Cambridge, United Kingdom, 659-740.

Ravishankara, A. R. et al. (2009) Nitrous oxide $\left(\mathrm{N}_{2} \mathrm{O}\right)$ : The dominant ozone-depleting substance emitted in the 21 st century. Science, 326, 123-125.

Sawamoto, T. et al. (2010) No significant difference in $\mathrm{N}_{2} \mathrm{O}$ emission, fertilizer induced $\mathrm{N}_{2} \mathrm{O}$ emission factor and $\mathrm{CH}_{4}$ absorption between anaerobically digested cattle slurry and chemical fertilizer applied timothy (Phleum pratense L.) sward in central Hokkaido, Japan. Soil Sci. Plant Nutr., 56, 492-502.

Shimizu, M. et al. (2009) The effect of manure application on carbon dynamics and budgets in a managed grassland of Southern Hokkaido, Japan. Agric. Ecosyst. Environ., 130, 31-40.

Shimizu, M. et al. (2010) Nitrous oxide emissions and nitrogen cycling in managed grassland in Southern Hokkaido, Japan. Soil Sci. Plant Nutr., 56, 676-688.

Shimizu, M. et al. (2013) The effect of fertilizer and manure application on $\mathrm{CH}_{4}$ and $\mathrm{N}_{2} \mathrm{O}$ emissions from managed grasslands in Japan. Soil Sci. Plant Nutr., 59, 69-86.

Shimizu, M. et al. (2014a) Farmyard manure application mitigates greenhouse gas emissions from managed grassland in Japan. In Sustainable Agroecosystems in Climate Change Mitigation, ed. Oelbermann, M., Wageningen Academic Publishers, Wageningen, Holland, 115-132.

Shimizu, M. et al. (2014b) Mitigation effect of farmyard manure application on greenhouse gas emissions from managed grasslands in Japan. In Soil Carbon, eds. Hartemink, A. E. \& McSweeney, K., Springer International Publishing, Cham, Switzerland, 313-325.

Soussana, J. F. et al. (2010) Mitigating the greenhouse gas balance of ruminant production systems through carbon sequestration in grasslands. Animal, 4, 334-350.

Toma, Y. et al. (2010) Aboveground plant biomass, carbon, and nitrogen dynamics before and after burning in a seminatural grassland of Miscanthus sinensis in Kumamoto, Japan. Glob. Change Biol. Bioenergy, 2, 52-62.

Toma, Y. et al. (2012) Carbon sequestration in soil in a seminatural Miscanthus sinensis grassland and Cryptomeria japonica forest plantation in Aso, Kumamoto, Japan. Glob. Change Biol. Bioenergy, 4, 566-575.

Toma, Y. et al. (2013) Soil carbon stocks and carbon sequestration rates in semi-natural grassland in Aso region, Kumamoto, southern Japan. Glob. Change Biol., 19, 16761687. 